\title{
Estafet Writing Technique in Teaching Writing Recount Text at Pesantren An-Nur Padangsidimpuan in Covid-19 Era
}

\author{
Seriani Hutasuhut ${ }^{1}$, Eka Sustri Harida ${ }^{2}$, Sri Rahmadhani ${ }^{3}$ \\ IAIN Padangsidimpuan \\ Email: ${ }^{*}$ seriani.zhaa11@gmail.com, 2haridaekasustri75@gmail.com, \\ ${ }^{3}$ srahmadhani15@gmail.com
}

\begin{abstract}
Abstrak
The main focus of the research is to find out the effect of Estafet Writing Technique on writing Recount Text at Grade XI Pesantren An-Nur Padangsidimpuan in Covid-19 era. This research was designed with quantitative research with experimental method. The sample were XI 1 as experimental class that consisted of 11 students and XI 2 as control class that consisted of 10 students. The data were collected through pretest and post-test in essay test form and analyzed by using t-test formula. The finding showed that the mean score of experimental class was higher than the mean score of control class. After doing T-test, the researcher found that $t_{\text {count }}>t_{\text {table }}(6.49>2.093)$. Therefore, alternative hypothesis $\left(\mathrm{H}_{\mathrm{a}}\right)$ of this research was accepted null hypothesis $\left(\mathrm{H}_{0}\right)$ was rejected. It can be concluded that there was significant effect of using Estafet Writing Technique on writing Recount Text at grade XI students of MA An-Nur Padangsidimpuan in Covid-19 Era.
\end{abstract}

Key Words : Estafet Writing Technique, Writing Recount Text.

\begin{abstract}
Abstrak
Fokus utama penelitian ini adalah untuk menemukan pengaruh dari Teknik Menulis Berantai dalam penulisan Teks Recount kelas XI Pesantren An-Nur Padangsidimpuan di masa Covid-19. Penelitian ini didesain dengan penelitian kuantitatif dengan metode eksperimental. Sampelnya merupakan kelas XI 1 sebagai kelas eksperimen yang terdiri dari 11 siswa. Dan kelas XI 2 sebagai kelas kontrol yang terdiri dari 10 siswa. Data dikumpulkan melalui pre- test dan post-test dalam bentuk tes essay dan dianalisis menggunakan rumus t-test. Hasil analisis menunjukkan bahwa nilai rata-rata kelas eksperimen lebih tinggi dari pada kelas control. Setelah melakukan T-test, peneliti menemukan bahwa $t_{\text {count }}>t_{\text {table }}(6.49>2.093)$. $\mathrm{H}_{a}$ dari penelitian ini diterima sedangkan $\mathrm{H}_{0}$ ditolak. Dengan demikian dapat disimpulkan bahwa terdapat pengaruh yang signifikan pada penggunaan Teknik Menulis Berantai terhadap penulisan Teks Recount kelas XI MA AN-Nur Padangsidimpuan pada masa Covid-19.
\end{abstract}

Kata Kunci : Teknik Menulis Berantai, Menulis Teks Recount 


\section{INTRODUCTION}

Writing is an activity to arrange or relate some words, phrases, sentences, and paragraphs become a good written text. Furthermore, writing related to the process of describing a language to produce a message so that will be has meaning. With writing, people can get lots of knowledge in daily life especially to support the activity in educational aspects.

Composing expertise is one of the language abilities which are vital to be learned in all old enough of school. As stated by Weigle, composing is a significant piece of the educational program in schools from the most punctual grades forward, most of children that have formal education system will learn to write, at least at a basic level, in that setting (Weigle 2002:5). In Indonesia, writing has been learned since Kindergarten School even just writing some vocabulary words.

Since the end of 2019, the world has been colonized by corona virus (Covid-19). For minimizing the transmission of covid-19, social distancing is applied to a certain actions such learning process in school. Covid-19 makes the learning process becomes complex and give more challenge for all teachers especially English teachers at Pesantren An-Nur Padangsidimpuan. English teacher have to find good and effective technique to teach students writing skill even during the covid-19 era.

Many students do not like writing lesson because they considered writing is complicated or the way of lesson may monotonous. It is supports with Westwood statement that written language perhaps the most difficult of all skills to acquire because the development involving the effective coordination of many different cognitive level, linguistics and psychomotor processes (Westwood 2008). The knowledge about how to arrange an interesting paragraph, how to think of the idea, also how to have an adequate vocabulary are important to establish an effective coordination of paragraph.

From the explanation, the researcher concluded that writing is very important to be learned by the students of English learner. Teaching a foreign language especially English is not easy as teaching the first language. If the students or teacher learn a foreign language, they will meet many methods, approaches or technique to help the students in learning process. In this case, an effective technique is needed to make the process of learning become interesting.

One way to motivate students in learning language process is by using an effective technique. The teacher should try to make attractive technique to attract students become interest to write actively (Saragih and Rabbani 2017:15). 
Using an effective technique makes students more creative and interesting about the topic of learning and not making the students are lazy to past the lesson.

In this research the researcher used Estafet Writing Technique as a technique to solve the problem above. In this technique, the learners take turns to tell a story in group, each one taking over from, and building on, the contribution of their classmates, at a given signal from the teacher (Thornbury 2005:96). All of students in the classroom must be active and do their best to make a good paragraph with enjoyable activity. Therefore, it enables the students more understand and the learning activity more fun and relaxed. In conclusion, it can help the students express their opinion or imagination for creating the narrative text easily.

Several related studies have been conducted to see how the students recount text by using Estafet Writing Technique. The first is Sri Lahir (2017) whose aimed of the research was to improve the ability to write recount text. The difference of this research with the research above is located in the type of the research design that was applied Classroom Action Research (CAR). The second is Dewi and Nirmala (2018) who did a research on Experimental type and found that Estafet Writing Technique has significant effect on writing ability. The third is Ariyani (2015). This research used chained picture to support her research. The result also has an effective result, the students have positive responses after being taught by using Estafet Writing with Chained Picture.

The forth is the research by Ditya (2017), with the result of this study is expressed to be effective, because there was the significant effect of estafet writing technique to students' writing narrative text. Another earlier research is by Ariesta (2021), the objective of the research were to find out the teaching writing online strategies and the students response of teaching writing online strategies in the middle of Covid-19 pandemic. The result showed that the strategies helped the teacher to teach writing online easier. All of the related findings above can be a consideration for researcher to do a further research, so, this research was done.

Further, the novelty of this research can be stated as the condition of the location of the research. The research above were done in general schools where learning English was done effectively, however, this research was done in the boarding school, or pesantren where learning English was not done so effective, not only in the condition of Covid-19 era, but even in the normal situation. In this Covid-19 era, many schools did online learning, but this school is done the learning process in the classroom with applying healthy protocol. 
Regarding the explanation above, it is important to investigate the further research on using Estafet Writing Technique. The aims of this research are to see the students' writing recount text before and after using this technique to the students of Pesantren An-Nur Padangsidimpuan in Covid-19 era and to examine the effectiveness of this technique on students' writing recount.

\section{THEORETICAL DESCRIPTION}

Writing is an activity to form notes, a written text or words to create something that very useful to daily life. That similar with Harmer's opinion, writing is a basic language skill, just as important as speaking, reading and listening. Students need to realize how to compose letters, set up composed reports, replay ad, and progressively, how to compose utilizing electronic media (Harmer 1998:79). All this kind piece of writing is very important to be learned for learners.

Based on Lubis (2014:61), writing is an activity for generating and conveying ideas, consist of phrases and sentences than expressing the meaning of ideas; and the activity to transfer ideas through words and Therefore, writing it is self can be read by another people as a product of some ideas that has meaning.

From above explanation, the researcher can get the conclusion that writing is a process of finding ideas to share understanding to the reader through sentence or paragraph. By doing writing activity, we can write all things so it can be shared to the young generation as a final piece of written text.

Nowadays, Estafet Writing is a kind of trick to teach writing (Piga 2017:36). It is a technique of cooperative writing that all member of group must write a paragraph individually. Students work in groups, each group pours their feelings into pieces of text; which is done in chaining sentences (Sari 2017:48). This makes all the students in the class active became a participant and the activities in the classroom become based on students' center.

Internationally, it is also called as chain writing. Thornburry (2005). said in chain story, the learners take turns to tell a story in group, each one taking over from, and building on, the contribution of their classmates, at a given signal from the teacher. The only one definition that researcher choose as the prime theory is the theory from Thornburry. This theory covers all of the theories about Estafet Writing Technique.

Based on Thornbury, the advantages of Estafet Writing Technique can make the students active and enthusiastic to follow the teaching and learning process because all the learners have to take turns to tell the story in a group 
(Thornbury 2005). Estafet Writing also can create a funny atmosphere and make the students more careful in learning. It is because the learning process is controlled by the teacher

Through its technique, teacher can increase the students' achievement in learning narrative text and the learning will be more enjoyable and interesting. According to Syathariyah as cited in Ditya (2017) the steps are as follows: 1) making groups 5-6 people, 2) in the group, the first person makes an opening sentence, 3) teacher tells the students to hand over the book to their right, 4) the second person continues to write their essay by adding a further sentence; it is continuing of the first sentence, 5) the next students to count again to the next students in the right, so it goes clockwise, until the time is up, 6) When the time is up, exercise book should be returned to the owners; the owners will read the results of essay written and mark the incorrect sentence, 7) the teacher asks one person writes the essay result on the board, and 8) the teacher and the students check together.

According to Ariyani (2015) the steps are as follow:

a. Dividing students into groups consists of 6-8 students.

b. Dividing chained picture for each group.

c. Giving explanation about the rules of the technique.

d. One student writes finishing, distributed the paper to the next student. Students should write their name at the end of their paragraph.

e. Managing the distribution of the paragraph, reminding the students to write paragraphs based on the picture, and the paragraph must be in relation one each other.

f. After finishing writing all of paragraph, all of group members have to revise their work together.

The next topic that should be discussed is Recount Text. Recount text is a text that telling the reader about something that happened in the past. It is supported by Miner and Zidnay, recount text tells about a specific person or event and it is organized as a series through time (Miner and Jitnay 2012). The events can be described the author's personal experience, someone else experience, or historical event.

According to Palmer in Senjawati, the purpose of recount text is to retell several events and usually it is from the point of view of someone who was there in a certain situation (Senjawati 2016). In addition, Stubbs also stated that some recounts will be purely informative, while others will aim to both inform and entertain (Stubbs and Wood 2000:8). A good recount text can make the readers or 
listeners interested and can feel such fear, happy, proud or may disappoint while reading the text.

Generic structure is divided into Two stages with one optional (Azhar 2015), they are: 1) Orientation (introduction), it contains the thesis of the text. 2) Series of events, beginning from the first, followed by the second event the last event and Re-orientation as optional, concluding the recount by summarizing outcomes or results. Orientation and series of events must exist in recount text. It gives more explanation in order to make the story clear and easy to understand. There are several language features in writing recount text (Stubbs and Wood 2000): First is using Simple past tense, using adjectives (specific descriptive word), contains a range of conjunctions (because, although, using time connectives (firstly, next, finally), passive sentence, adverbs (yesterday, outside), specific participants, and pronoun.

\section{RESEARCH METHOD}

This research used experimental quantitative method with pre-test and post-test design. The population were all of the students at grade XI Pesantren An-Nur Padangsidimpuan. The sample were XI 1 as experimental class that consisted of 11 students and XI 2 as control class that consisted of 10 students. In this research the sample took by using population sampling where all of the students becomes a sample. The data were collected through pre-test and posttest in essay test form and analyzed by using t-test formula.

\section{RESULT AND DISCUSSION}

The results showed that many students' score in both of classes are increased. In experimental class, they were 11 students (XI 1), some of them raising score and their score increased very significant. In control class consisted of 10 students (XI 2), most of students score also increased but not significant or it can be said that their score increased slightly.

The researcher found that the total score in experimental class was higher than the total score in control class in post- test. The higher score of experimental was 91 and the highest score in control class was 80 . The lowest score of experimental in post- test was 60; meanwhile in control class was 49 . To make the easier in seeing the comparison of the data, the researcher presented them in this following table. 
The Comparison Data of in Post-test

\begin{tabular}{ccc}
\hline \hline Descriptive & Experimental Class & Control Class \\
\hline \hline Total Score & 811 & 647 \\
\hline High Score & 91 & 80 \\
\hline Lowest Score & 60 & 49 \\
\hline Mean & 75.09 & 66 \\
\hline Median & 74.6 & 74.5 \\
\hline Modus & 75.6 & 74.12 \\
\hline Range & 31 & 31 \\
\hline Interval & 7 & 7 \\
\hline Standard Deviation & 9.09 & 10.84
\end{tabular}

To get the data description of both of classes, the researcher presented them into this following histogram.

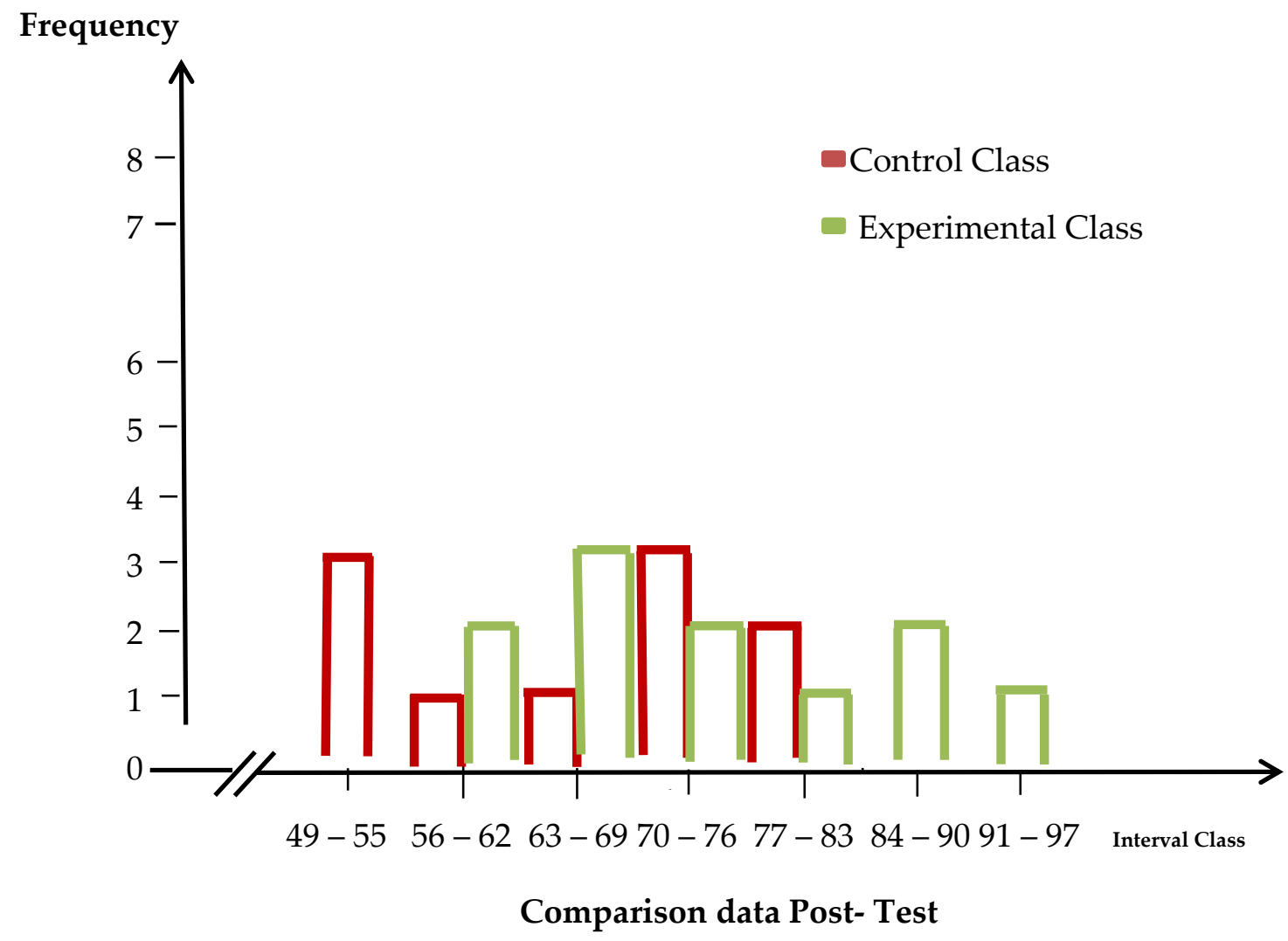

The figure above described the students score based on the interval class. It can be seen the comparison the lowest score and the highest score of 
experimental and control class in post- test. The lowest score was shown at the first diagram. Besides, the lowest score at the last diagram. The green diagram showed the experimental class, while the red one showed the control class.

From histogram above, in experimental class the frequency of the students from 49 - 55 was 0 (none students); 56 - 62 was 2 students; 63 - 69 was 3 students; 70 - 76 was 2 students; 77 - 83 was 1 student; 84 - 90 was 2 students and 91- 97 was 1 student. In control the frequency of the students from $49-55$ was 3 students; 56 - 62 was 1 student; 63 - 69 was 1 student; 70 - 76 was 3 students; 77 - 83 was 2 students, 84 - 90 was 0 (none students) and 91 - 97 was 0 also (none students).

The researcher also used parametric test by using T-test formula in analyzing the hypothesis. After counting the data of post - test, it found that the result is normal and homogenous. Hypothesis alternative $\left(\mathrm{H}_{\mathrm{a}}\right)$ of the research was "There was significant effect of using Estafet Writing Technique on Students Writing Recount Text at pesantren An-Nur Padangsidimpuan in Covid-19 Era".

The result of $\mathrm{t}$-table above was found after calculating the data by using $\mathrm{t}$ test formula. The hypothesis test was two criteria. They are if $\mathrm{t}$-count $<\mathrm{t}$-table $\mathrm{H}_{\mathrm{o}}$ is accepted. And if $t$-count $>t$-table $\mathrm{H}_{\mathrm{a}}$ is accepted. Based on the researcher calculation in pre- test, the researcher found that $t$-count 1.73 while table 2.093 with opportunity $(1-\alpha)=1-5 \%=95 \%$ and $\mathrm{dk}=\mathrm{n}_{1}+\mathrm{n}_{2}-2=19$. Cause $\mathrm{t}$-count $<\mathrm{t}$-table $(1.73<2.093)$, it means that hypothesis $\mathrm{H}_{a}$ was rejected and $\mathrm{H}_{0}$ was accepted. So, in pre-test, the two classes were same. There is no difference in both of classes. But in post- test, the researcher found that $\mathrm{t}$-count 6.49 while $\mathrm{t}$-table 2.093 with opportunity $(1-\alpha)=1-$ $5 \%=95 \%$ and $d k=n_{1}+n_{2}-2=19$. Cause $t$-count $>t$-table $(6.49>2.093)$, it means that the hypothesis $\mathrm{H}_{a}$ "there was significant effect of using Estafet Writing Technique on students writing Recount Text at grade XI Pesantren An-Nur Padangsidimpuan was accepted. The result of $t$-test was as follow:

Result of T-Test from the Both Average

\begin{tabular}{cccc}
\hline \multicolumn{2}{c}{ Pre- Test } & \multicolumn{2}{c}{ Post Test } \\
\hline$t_{\text {count }}$ & table $_{\text {tabount }}$ & $t_{\text {table }}$ \\
\hline 1.73 & 2.093 & 6.49 & 2.093 \\
\hline
\end{tabular}

By the result of the calculation of t-test above, it can be concluded that there was significant effect of using estafet writing technique on writing recount text at Pesantren An-Nur Padangsidimpuan in Covid-19 era. In this case, the 
mean-score of experimental class after using estafet writing was 75.09 and mean score of control class by using teacher technique was 66. The gain score was 9.09. The calculation can be seen in the following table:

\begin{tabular}{cccc}
\multicolumn{4}{c}{ Gaining Score of Experimental Class and Control Class } \\
\hline \hline Class & Pre -Test & Post- Test & Gain score \\
\hline Experimental & 44.5 & 75.09 & 30.59 \\
\hline Control & 47.1 & 66 & 18.9 \\
\hline
\end{tabular}

It can be seen in the above table that the gaining score of students at class of experiment was 30.59, while the students' gain score at control class was 18.9. It can be said that students' score of experimental was higher than the students' score in control class.

In data analysis, the researcher discussed the result of this research on the effect of using Estafet Writing Technique on Students' Writing Recount Text, where the result mean score experimental class was higher than control class. The mean score of experimental class after using it was 75.09 and mean score of control class by using teacher technique was 66. It has been discussed by Saragih and Rabbani stated that estafet writing was positive and effectively perceived on implementing in teaching writing (Saragih and Rabbani 2017). It can be concluded that estafet writing is very useful for writing recount text not only to help them in writing but they also feel enjoy and interested.

The same result also found by Sri Lahir (2017). It is seen that the application of the method can improve the ability to write text recount from the initial condition of average value of 70 with completeness of $54.54 \%$ to the final condition in cycle II average 85 with completeness $86.36 \%$. Thus, it can be said that through the method of writing relay can improve the ability to write recount text. The second is Andika Api Asmara Ditya's research (Ditya 2017). The analysis showed that $\mathrm{H}_{\mathrm{o}}$ was rejected and $\mathrm{H}_{\mathrm{a}}$ was accepted. It was showed that the Estafet Writing Technique is expressed to be effective to teach narrative text. So this thesis can be a consideration for researcher.

Another result also found by Mahmuda Rangkuti's research (Rangkuti 2017), that the implementation of the Estafet Writing Technique made learning writing is more active and interesting and the students' ability in writing narrative text was improved. Therefore, it can be said that this technique is one of effective techniques that used in learning English writing. 
Finally it can be stated that many previous research stated that it was proved that the students' score that taught by using estafet writing got better score. As in the research, it was also proved that the mean score of experimental class in post- test got higher result then in control class $(75.09<66)$. After looking the students' score in experimental class after using Estafet Writing Technique in teaching recount text, this technique can help the students to develop their interest and ideas in written form. Based on the result, it also can be stated that whether the Covid-19 spread in many cities, in this school the learning process was still done. Although many teachers and schools faced many problems (Harida 2020), Pesantren An-Nur is still exist in educating the students. Covid-19 era is not a significant problem for the learning situation in this school.

\section{CONCLUSION}

The conclusion of this research is the students' writing recount text at grade XI students Pesantren An- Nur Padangsidimpuan before learning by using estafet writing technique in experimental class was in low category, it was at 44.36, and after learning using it was 81 . It also can be seen the higher score after using estafet writing technique (experimental class) was 91 and the lowest score was 60 . It can be seen from the result of $t$-test, $t_{\text {count }}$ was higher than table $(6.49>$ 2.093). It means that the hypothesis, $\mathrm{H}_{a}$ was accepted and $\mathrm{H}_{0}$ rejected. So, it can be stated that there was significant effect of using estafet writing technique on students' writing recount text at Pesantren An-Nur Padangsidimpuan in Covid19 Era. 


\section{REFERENCES}

Ariesta, May Lien Tia Candra. 2021. “Teaching Writing Online Strategies During Covid-19 Pandemic." Language Education Vol.10 (No.4).

Ariyani, Zulfah. 2015. "The Use of Estafet Writing with Chained Picture to Improve Students Narrative Text." UIN Walisongo.

Azhar, Syaiful. 2015. "Analysis of Generic Structure of Recount Texts." IAIN Salatiga.

Dewi, Nensi Arfika, Hiqma Nur Agustina, and Nirna Nirmala. 2018. "The Effect of Estafet Writing in Teaching Writing at the Eleventh Grade Students of SMAN 20 Kabupaten Tangerang" Vol.27.

Ditya, Api Andika Asmara. 2017. “The Effectiveness of Estafet Writing in Teaching Writing of Narrative Text." Surakarta: IAIN Surakarta.

Harida, Eka Sustri. 2020. "Students' Learning in Corona Virus Diseases 2019 (Covid-19) Situation." English Education: English Journal for Teaching and Learning 08 (01): 25-37. https://doi.org/10.24952/EE.V8I01.2675.

Harmer, Jeremy. 1998. How to Teach English. England: Longman.

Lahir, Sri. 2017. "Improving Writing Recount Text Ability Through Estafet Writing Method Grade XI SMP Negeri Sukoharjo." Edunomika Journal Vol.1.

Lubis, Rayendriani Fahmei. 2014. “Writing Narrative Text." English Education Vol.02: 76 .

Miner, Darla, and Jill Jitnay. 2012. Exploring Non-Fiction with Young Learners. America: Rowman \& Littlefield Education.

Piga, Gabriel Hibu. 2017. "Improving the Eleventh Grade of SMA N1 Raijua in Writing Narrative Text Through Estafet Writing Teaching Model in Academic Year 2016/2017." International Journal of English and Education Vol.6 (4).

Rangkuti, Mahmudah. 2017. "The Use of Estafet Writing Method to Improve Students' Ability in Writing Narrative Text at the 8 Grade Students of SMP N 17 Medan." Medan: State Islamic University of North Sumatera.

Saragih, Enni Erawati, and Anggi Nur Fitri Rabbani. 2017. "Teacher Perceptions on Implementing Estafet Writing Technique in Teaching Writing." English Journal Vol. 20 (2). 
Sari, Putri Winda. 2017. "The Use of Estafet Method in Improving Students Narrative Writing Skill at Grade X of SMA Persada." Journal Linguistika Vol.8: 52.

Senjawati, Dessy. 2016. “Transitivity Analysis of Tenth Grade Students' Recount Texts." Journal of English and Education 4 (1).

Stubbs, Sue, and Katrina Wood. 2000. Targeting Text. Sidney: Blake Education.

Thornbury, Scott. 2005. How to Teach Speaking. Logman.

Weigle, Sara Cushing. 2002. Assesing Writing. New York: Cambridge University Press.

Westwood, Peter. 2008. What Teachers Need to Know about Reading and Writing Difficulties. Victoria: Acer Press. http://gen.lib.rus.ec/book/index.php?md5=7C3DBF236820F8C04B1F9EFB6 995E866. 